\title{
COLLOQUIA
}

\begin{tabular}{|c|c|}
\hline & $\begin{array}{c}\text { Forum Pedagogiczne } \\
11(2021) 1\end{array}$ \\
\hline BARBARA MAŁGORZATA KAŁDON* & $\begin{array}{r}\text { Wpłynęło: } 28.12 .2020 \\
\text { Zatwierdzono do druku: } 15.03 .2021 \\
\text { DOI: } 10.21697 / \text { fp.2021.1.15 }\end{array}$ \\
\hline Warsaw, Poland & \\
\hline
\end{tabular}

\section{CHILD PROTECTION FROM THE CIVIL LAW PERSPECTIVE - SELECTED ISSUES ${ }^{* *}$}

\begin{abstract}
Care for the well-being of the youngest family members is one of the main goals of the legislator. A properly functioning family does not require an interference of the officials as long as it does not deviate from the generally accepted standards. However, if such a situation occurs, it is necessary to undertake legal mechanisms aimed at restoring the proper functioning of the family. Consequently, various branches of the law regulate instruments to help the family overcome the crisis.

The article presents selected areas of civil law child protection referring to such issues as prohibition of using corporal punishment against a minor and the consequences of its violation, other forms of abusing parental authority, as well as the regulation of certain relations between parents and children.
\end{abstract}

Keywords: child protection, civil law, corporal punishments, child abduction aspects, relationships between parents and children.

\section{Introduction}

Approach to children as independent human beings and perception of their interests as deserving special protection in the legal system and in social life, are among the major issues related to human rights (Radwański 1991, 53). Due to their age, children sometimes enjoy special protection, exceeding that offered to other age groups. It is necessary to grant such protection due to the fact that children lack

* Barbara Małgorzata Kałdon, PhD - assistant professor at the Cardinal Stefan Wyszyński University in Warsaw. The author's research interests focus on issues related to criminology, criminal law, and family and guardianship law; e-mail: barbara.m.k13@gmail.com.

** This article was printed on the same title in Polish. 
physical or mental maturity, which means that they are generally unable to protect themselves against, or to recover from a situation that threatens their life and health. (Konarska-Wrzosek 1999, 9). International legislation regulating protection of children's rights does not provide full legal protection of children if it fails to take into account national regulations that allow to assess the scope of children's protection against any form of violating their interests, because whatever the catalog of international laws may be, the leading role in ensuring their implementation is played by a country's internal legislation as well as its social and political system (Sitarz 2004, 28). In view of the above, special rights have been established for the minors, taking into account the needs resulting from their immaturity as well as the need to provide all children with appropriate conditions for development and education. (Sitarz 2004, 28).

The aim of this article is to present, mainly from the theoretical point of view, selected issues in the field of civil law child protection. The author has employed an interpretative-descriptive methodology, specific primarily for legal professions (Dobosz 2001, 24), using the purposeful method of interpretation, which consists in an attempt to find the goal the legislator wanted to reach when issuing a given regulation (Łętowski 1995, 45).

In the first part of the article, particular attention will be paid to the aspect of prohibiting the use of corporal punishment against minors and sanctions associated with violating that prohibition. The second part of the article will be devoted to issues associated with relations between parents and children. Those will include, among others: establishment or denial of paternity along with determining the ineffectiveness of paternity recognition, resolution of adoption, as well as the court's right to decide on important matters of the child and the issue of activities exceeding the scope of the ordinary management of the child's property.

\section{Prohibition of corporal punishment}

Art. $96^{1}$ of the Family and Guardianship Code (the FGC) added by Art. 2 of the Act of 10.06. 2010 on amending the act on counteracting domestic violence and some other acts, is one of the main civil law provisions protecting children. It introduced a ban on the use of corporal punishment against children. This provision refers, inter alia, to Art. 72 section 1 sentence 2 of the Polish Constitution, according to which everyone has the right to demand that public authorities protect children against violence.

It should be noted, however, that in some situations Art. $96^{1}$ of the FCG is not applicable due to admissibility of behaviors constituting the only available means of showing disapproval, such as "spanking" a few-year-old child in cases of repeated, ineffective persuasion (Gajda 2020, 798). Moreover, the above-mentioned provision does not exclude the possibility of using physical coercive measures against a child, for example, in order to administer a medicine (Gajda 2020, s. 798). Parents can 
also use the defense of necessity, for example to protect the child from aggressive behavior of an older sibling (Sokołowski 2013, 667-668).

The phenomenon of disciplining children in the family is a problem that is widely discussed at various social levels. This can undoubtedly be caused by cases of parental authority abuse consisting in severe beatings of children by their own parents presented by the media. Over the years, a number of publicized cases of abusing parental authority have sparked a discussion on the issue of disciplining children as an parenting method.

Literature fails to provide a uniform definition of the concepts of violence / maltreatment of children. For example, Andrés Soriano proposes to treat these concepts as "any kind of physical or psychological damage that a child experienced in a nonaccidental manner before the age of eighteen, caused by persons or institutions, whether as a result of physical, sexual or emotional action, or neglect, and which threatens the child's normal physical and psychological development" (Soriano 2002, 41).

On the other hand, maltreatment of children can be classified in various categories:

- based on its character and form: physical, mental or emotional abuse;

- based on the manner of its occurrence: e.g., through action (active) - the child is injured physically, mentally, or sexually; through neglect (passive) by the child's basic needs are neglected;

- based on the place of its occurrence: in the family; outside the family (Soriano 2002, 42).

Violation of the abovementioned prohibition of using corporal punishment against a child may result in a lawsuit. The measures provided for in Art. 109 of the FGC aimed at restricting parental authority can be applied, and in case of circumstances specified in Art. $111 \S 1$ and 1a of the FGC - the guardianship court will deprive parents of parental authority. The court, having regard to the best interest of the child, may also limit or restrain the parents' contact with the child. According to Aleksandra Wilk, if the guardianship court considers issuing a decision to limit parental authority, it would be justified for the court to ask the family support unit for information on the planned and most effective forms of support for the family in question (Wilk 2019, 244).

In addition, regulations contained in the Act of 29.07.2005 on counteracting domestic violence can be used in this case. According to Damian Gil, the amendment to the above-mentioned act will lead to many instances of abuse by social workers, whose actions may contribute to traumatic experiences of children (Gil 2011, 121-122). According to the Author, the legislator has completely overlooked the role of the family and guardianship court in the process of parental authority limitation / deprivation (Gil 2011, 122).

The table below provides sample statistics on the cases of deprivation, suspension and limitation of parental authority: 
Table 1. Deprivation, suspension, limitation of parental authority in the years 2000-2019 (first half of the year)

\begin{tabular}{|c|c|c|c|}
\hline & Deprivation of p.a. & Suspension of p.a. & Limitation of p.a. \\
\hline 2000 & 4410 & 616 & 12352 \\
\hline 2001 & 4176 & 567 & 11919 \\
\hline 2002 & 4411 & 682 & 11057 \\
\hline 2003 & 5051 & 700 & 14086 \\
\hline 2004 & 5969 & 728 & 16639 \\
\hline 2005 & 6788 & 739 & 17670 \\
\hline 2006 & 7448 & 744 & 20128 \\
\hline 2007 & 7840 & 756 & 20541 \\
\hline 2008 & 8257 & 608 & 20026 \\
\hline 2009 & 8532 & 759 & 19576 \\
\hline 2010 & 9142 & 740 & 18848 \\
\hline 2011 & 9098 & 697 & 15984 \\
\hline 2012 & 9668 & 660 & 14085 \\
\hline 2013 & 10309 & 567 & 14411 \\
\hline 2014 & 10236 & 590 & 14380 \\
\hline 2015 & 10675 & 526 & 13545 \\
\hline 2016 & 10138 & 565 & 12876 \\
\hline 2017 & 9184 & 489 & 12637 \\
\hline 2018 & 9404 & 465 & 11898 \\
\hline $2019-1^{\text {sthalf }}$ & 4942 & 240 & 5942 \\
\hline
\end{tabular}

Source: Open Data. Department of Statistical Management Information. Department of Strategy and European Funds. Ministry of Justice (accessed: 19/o9/2019).

Based on the above data, it can be noted that the statistics regarding limitation of parental authority are significantly predominant, especially in the years 2006-2008. Research by Olga Trocha shows that the prevailing cases regard limiting parental authority of both parents $-46 \%$, less often the father's parental authority $-35 \%$ or the mother's $-19 \%$ (Trocha 2015, 58). This procedure is initiated after information from various persons and entities has been submitted to the court, and it is often one of the parents - the mother in $24 \%$ of cases, and the father only in $2 \%$ (Trocha 2015, 58). On the other hand, information regarding a threat to the child's wellbeing submitted by individuals outside of the family, most often comes from the police $-19 \%$ and educational institutions $-18 \%$ (Trocha 2015, 58). According to the data from the Ministry of Justice, the highest rate of parental authority deprivation occurred in the years 2013-2016, and in Poland there are definitely fewer cases of parental authority suspension compared to its deprivation or limitation. What gives rise to considerable concern is a relatively increasing number of parental authority deprivations over the years. A slight decrease in this respect has been noticed since 2017. According to the research by Elżbieta Holewińska, it can be stated that most often, namely in $62.5 \%$ of cases, proceedings for deprivation of 
parental authority are instituted ex officio, on the initiative of mothers in $25 \%$ of cases, while fathers demanded deprivation of rights of mothers in $6.3 \%$ of situations (Holewińska-Łapińska 2013, 41).

An important regulation in the field of civil law child protection is Art. $579^{1} \S_{2}$ of the Civil Procedure Code (the CPC). Based on this regulation, when the child is placed in foster care under Art. 12a of the Act of 29 July 2005 on counteracting domestic violence, the court, after hearing the social worker who removed the child from the family, immediately, but not later than within 24 hours, issues a decision to place the child in foster custody or to return the child to the family. This act provides a definition of the concept of domestic violence as a one-time or repeated deliberate act or neglect violating the rights or personal interests of family members, in particular endangering their life or health, violating their dignity, physical integrity, freedom, including sexual freedom, causing physical or mental impairment, suffering and injury to feelings of people affected by violence. The grounds for a child removal by social services include: direct threat to the minor's life / health associated with domestic violence, as well as a decision made together with a Police officer and doctor, paramedic or nurse. According to Art. 12b of the Act on counteracting domestic violence - parents, legal or de facto guardians are entitled to file a complaint to the guardianship court in connection with the child's removal. The court examines such a complaint immediately, but not later than within 24 hours. If it is decided that the removal of the child is unwarranted or illegal, the court orders to place him or her immediately with an authorized person. On the other hand, according to $\$ 3$ of the aforementioned provision, the guardianship court periodically, at least once every six months, assesses the situation of the child placed in foster care in order to determine the possibility of the child's return to the family. If the best interests of the child so require, the court will initiate proceedings to deprive parents of parental authority.

Moreover, it cannot be ruled out that any act of violating the prohibition under Art. $96^{1}$ of the FGC, may give grounds to applying the provisions of the Criminal Code. This may include Art. 207 of the Criminal Code concerning physical or mental abuse of a closest relation. In turn, in the field of substantive civil law (the Civil Code), Art. 24 of the Civil Code and Art. 448 of the Civil Code may also be applied due to the fact that physical integrity has been included in the list of personal rights (Uchwała 1971), whereas, in cases of bodily injury or health disorders resulting from the violation of the child's physical integrity, Art. 444-446 of the Civil Code.

The regulation contained in the discussed article covers a wide range of people exercising parental authority over the child, and apart from biological parents, it also includes adoptive parents, guardians, foster parents, or persons running a family orphanage. Therefore, the provision of Art. $96^{1}$ of the FGC, does not distinguish between the legal position of parents and that of other persons to whom this provision applies, however, in this respect, one should remember to take into account the specific legal position of parents resulting from their natural right to 
personal relationships with their children. The above right is defined in Art. 48 section 1 of the Polish Constitution.

\section{Child abduction}

Moreover, attention should be paid to the provisions of Art. $569^{1}$ of the Code of Civil Procedure, in accordance with $\$ 1$ thereof, "the jurisdiction of the district court with its seat in the place which is the seat of the appellate court includes cases for the removal of a person subject to parental authority or remaining under guardianship carried out pursuant to the 1980 Hague Convention, if the person subject to parental authority or remaining under guardianship has the place of residence or stay in this area". The cited convention of 25.10 .1980 on the civil aspects of international child abduction aims to counteract parental child abduction or unlawful retention by establishing a system of cooperation among central authorities as well as a rapid return procedure. Another major objective of this convention includes safeguarding the visitation rights. In matters not covered by this convention, the court applies its own procedure.

In turn, according to Art. $570^{1} \$ 1$ of the Code of Civil Procedure "the guardianship court may order a court probation officer to conduct an environmental interview in order to collect information about the minor and his or her environment, in particular his or her behavior, upbringing and life conditions, including the living situation of the family, the minor's education and the way of spending free time, his or her contacts with the community, the attitude of parents or guardians towards him or her, the undertaken educational interactions, the minor's health condition and addictions known in the community". Such an interview is performed by a professional or social probation officer. It is most widely used in judicial practice as a source of objective information in the case, taking into account the opinion about the child and his or her family provided by the community (Jastrzemska $2019,106)$. The phrase "in particular" used in the aforementioned provision points to the guardianship court's broad powers regarding collection of data concerning the minor and his or her environment. The court may order a probation officer to collect other data, apart from that specified in that article, if it is justified by the type and nature of the case. Despite the phrase "the guardianship court may" used by the legislator, there is no doubt that whenever such a need arises, the guardianship court is obligated to use the means provided for in this paragraph to obtain information about the child's situation (Jastrzemska 2019, 106). It should be noted here that in accordance with Art. $216^{1} \$ 1$ of the Code of Civil Procedure, in cases concerning a minor, the court will hear him or her if his or her mental development, state of health and degree of maturity allow for it. This issue is similarly regulated in Art. $576 \$ 2$ of the Code of Civil Procedure. Fulfillment of the above conditions must be assessed by the court in the light of the circumstances of the case in relation to a specifically individualized child (Wyrok 13.12.2013). 


\section{Relations between parents and children - major issues}

The major issues with a regulation of relations between parents and children include, among others, the determination and denial of the child's origin, determination of the ineffectiveness of paternity recognition, a dissolution of adoption, as well as the court's decision on important matters of the child, and activities outside of the scope of the ordinary management of the child's property. Selected issues listed above will be presented below.

Pursuant to the Act, the Code of Civil Procedure, separate proceedings in cases concerning relations between parents and children apply in cases concerning establishing or contradicting the child's origin, establishing the ineffectiveness of paternity recognition and a dissolution of adoption. All these types of cases fall within the substantive jurisdiction of the district court (Civil Procedure Code Art.17 p. 1). Separate proceedings in the above-mentioned cases are obligatory and therefore cannot be combined with other cases falling into the scope of ordinary proceedings.

Determining that the declaration on child recognition was not submitted by a specific man leads to the denial of the child's origin and the necessity to change the civil-status record in this respect (Wyrok 6.02.2009). If a reference is made in the civil-status record regarding the child's recognition by the father, an action to establish that recognition did not take place is not admissible. In such a case, the mention regarding recognition of the child may be deleted from the civil-status record on the basis of the court's decision to correct the civil-status record. It should also be mentioned that, as a rule, the ex-wife of a man who recognized the child is not entitled to submit an application to correct the child's civil-status.

On the other hand, correction in the birth certificate of the allegedly misrepresented and incorrectly entered name of the child's mother may only take place after it has been ruled by the court that the child originates from another woman (similarly as in the case of the father). An action for denial and determination of maternity may be filed by a person directly and personally interested in the result of the proceedings (Wyrok 27.02.1967). It should also be emphasized that even if in certain cases it were possible to dismiss the action for denial of motherhood solely on the basis of the principles of social coexistence (Art. 5 of the Civil Code), then it would not be possible if the child knows the true state of affairs. It is because in such a case there is no fear that it will suffer a psychological shock or any other negative consequences (Wyrok 7.06.1976).

It is worth pointing out that the purpose of the proceedings for the denial of paternity is not to establish the biological paternity of the mother's husband, but to overthrow the statutory presumption that the child is fathered by him (Wyrok 13/12/200o). The Supreme Court points out that the fact that the mother's husband's family saw her with the child cannot provide basis for conclusions by presumption that the family knew about the defendant's giving birth to such a child and that it 
must not be deduced from this presumption that the family notified the plaintiff of the fact that the child was born (Wyrok 22.04.1977).

The issue of an adoption dissolution has long been discussed both in Poland and in other countries. The only procedure in Polish legislation for terminating this relationship is the court procedure. The provision of Art. $125 \$ 1$ of the FGC envisages two premises for the admissibility of dissolving adoption: existence of important reasons and the best interests of the child. Assumptions underlying the institution of adoption, may also provide basis for the third premise, namely, that of one of the parties' fault. The premise of important reasons, understood as breaking the family bond, is the basic premise for dissolving adoption both when the child is still a minor and when the child has already reached the age of majority. In the case of an adopted minor, it refers to the lack of everyday, emotional ties between parents and the child, and in the case of an adult - hostility or at least coldness, preventing the adopter and the adoptee from maintaining contacts typical of relations between parents and a child who lives independently (Gajda 2020, 977). It should be noted, however, that within the meaning of Art. $125 \$ 1$ of the FGC, the premise of important reasons does not take effect in a situation where, despite the fact that the bond between the adoptive parent and the adopted child has been broken, there is a strong family bond between the adoptee and, e.g., his or her grandparents, uncle or aunt. Pursuant to the judgment of the Supreme Court of 5 September 1975, assessment of important reasons should be made at the time of the court decision on dissolving adoption. On the other hand, when assessing whether the best interests of the child preclude an adoption dissolution, it is necessary to take into account whether the child will be deprived of the necessary care adequate to his or her age, whether he or she will be able to return to the natural family or placed in another family, i.e., whether the dissolution of adoption will not substantially deteriorate the child's situation (Gajda 2020, 980). Moreover, in assessing admissibility of dissolving adoption, it is important which party is at fault as regards the breakdown of the family ties. The above-mentioned provision does not directly indicate this premise, but such a premise is implied by the principles of social coexistence. In accordance with the jurisprudence of the Supreme Court, it should be indicated that, in principle, the party guilty of breaking the family ties may not instigate the proceedings aimed at dissolving adoption (Wyrok 2.12.1971). As explicitly stipulated by this article, the only parties authorized to initiate the proceedings aimed at dissolving adoption are the adoptee and the adopter.

In turn, according to Art. 582 of the Code of Civil Procedure - a decision regarding the child's important issues on which the parents disagree, may not take place until the parents are allowed to make their statements, unless hearing them would cause excessive difficulties. Such a decision on essential issues concerning the child may refer, inter alia, to: place of his or her stay, choice of school, method of medical treatment, spending holidays, developing interests, changing his or her name or citizenship (Uchwała 200o). 
As regards actions exceeding the scope of the ordinary management of the child's property or the parents' consent to allow the child to manage the property, pursuant to Art. 583 of the Code of Civil Procedure, it is necessary to obtain permission of the guardianship court granted at the request of one of the parents after hearing the other. Such a ruling may not be amended or repealed if it has produced legal effects for third parties. The substantive legal basis for activities exceeding ordinary management is regulated in Art. $101 \S 3$ of the FGC. Due to the fact that there is no legal definition of the concept of "action exceeding the ordinary management", the guardianship court should always assess its specific gravity, material effects and the value of its subject. The basic directive of guardianship court decisions should be, pursuant to Art. $95 \$ 3$ of the FGC consideration of the child's welfare and social interest. On the one hand, the child's welfare includes the sphere of his or her personal issues, including physical and spiritual development, appropriate education, upbringing and preparation for adult life, and on the other hand, it has a clear material character and consists in providing the child with means of living and achieving personal goals, and in the case of his or her property, also in caring for the child's financial interest (Postanowienie 1997).

\section{Conclusion}

In 2010, the Polish legislator introduced a ban on the use of corporal punishment, addressed to persons exercising parental authority / care or custody over the children. The ban is inopposition to the views of society that in various studies mostly supported admissibility of physical punishment of children, and also to the views of representatives of the science of law, who saw the relation of such upbringing methods, among others, with the application of the non-statutory justification of disciplining the minors (Krajewski 2010, 127-128). However, it should be noted that prohibition of physical punishment of children has the value of promoting appropriate parental and educational attitudes (Krajewski 2010, 127-128). It may probably result in fewer acts of violence, aggression, and thus cases of deprivation, suspension or limitation of parental authority. It should be noted that removal of the child (beaten, intimidated, neglected) sometimes requires drastic measures, but such a decision cannot be taken arbitrarily, and it should be made by a judicial body (Gil 2011, 122). The role of the prosecutor, court and other procedural bodies is of key importance in cases of exceeding the limits of permitted punishment, however, the procedural authority cannot interpret the behavior too suggestively and superficially, and only thoroughly conducted preparatory proceedings and a fair trial can show whether the limits of the justification were exceeded and what were the parent's / guardian's motives (Gil 2011, 122).

In addition, it is necessary to recognize the importance of the civil procedure provisions that protect the child from parental abduction and regulate the relationship between parents and children. Moreover, solutions relating to the 
possibility of dissolving adoption in the event of statutory premises are also significant. One of the Court's rights important for protecting the interests of the child is also the possibility of deciding on the child's essential issues, as well as the requirement of consent to activities exceeding the scope of the ordinary management of the child's property.

As Aleksandra Wilk rightly points out, the support measures undertaken by family support units as well as the acts of intervention or orders of the guardianship court regarding interference with parental authority present in the legal status in force two separate spheres of exerting influence on the family (Wilk 2019, 245). In the Author's opinion, such a combination of judicial influence on the family and of the local government support system may constitute an effective system of supporting families experiencing child-rearing problems. (Wilk 2019, 244).

Despite the fact that children's rights are protected by various branches of law, criminal law, having a subsidiary character here, certainly plays a significant role in providing this protection. However, as Olga Sitarz points out, there remains the question whether it properly serves the children's rights guaranteed in the Convention on the Rights of the Child (Sitarz 2004, 41). Undoubtedly, one of the main goals of the legislator is to care for the well-being of the youngest, and perhaps the practice and cooperation of institutions / bodies at various levels will provide even more extensive protection for this social group, especially with regard to parental abductions whose effects publicized in the media are sometimes devastating.

\section{Bibiography}

Dobosz P. (2001). Problemy metodologii wspótczesnej nauki prawa administracyjnego na tle metody historyczno-prawnej. „Kwartalnik Prawa Publicznego”, nr $1 / 1$, s. 9-47.

Gajda J. (2020). Kodeks rodzinny i opiekuńczy. Dział IA: Rodzice i dzieci. W: Kodeks rodzinny i opiekuńczy. Komentarz. Pietrzykowski K. (red.). Warszawa: Wydawnictwo C.H. BECK, wyd. 6, s. 779-870.

Gajda J. (2020). Kodeks rodzinny i opiekuńczy. Dział II: Przysposobienie. W: Kodeks rodzinny opiekuńczy. Komentarz. Pietrzykowski K. (red.) Warszawa: Wydawnictwo C.H. BECK., wyd. 6, s. 877-992.

Gil D. (2011). Rola organów procesowych w przypadku przekroczenia granic dozwolonego karcenia małoletnich. W: Prawne aspekty karcenia małoletnich. Ciepły F. (red.). Warszawa: Wolters Kluwer, s. 109-123.

Holewińska-Łapińska E. (2013). Orzecznictwo w sprawach o pozbawienie władzy rodzicielskiej. „Prawo w Działaniu Sprawy Cywilnej”, nr 14, s. 27-76.

Wydział Statystycznej Informacji Zarządzającej. Departament Strategii i Funduszy Europejskich. Ministerstwo Sprawiedliwości. Dostępny na: https://dane.gov.pl/ $\mathrm{pl} /$ dataset/287/resource/19553/table (dostęp 19.09.2019). 
Jastrzemska S. (2019). Postępowanie rozpoznawcze. Cz. 1. W: Kodeks postępowania cywilnego. T. II: Komentarz do art. 506-1217. Szanciło T. (red.). Warszawa: Wydawnictwo C.H. BECK, s. 66-172.

Jastrzemska S. (2019). Postępowanie nieprocesowe. Księga 2. W: Kodeks postępowania cywilnego. T. II: Komentarz do art 506-1217. Szanciło T. (red.). Warszawa: Wydawnictwo C.H. BECK, s. 66-172.

Konarska-Wrzosek (1999). Ochrona dziecka w polskim prawie karnym. Toruń: Towarzystwo Naukowe Organizacji i Kierownictwa „Dom Organizatora”.

Krajewski R. (2010). Karcenie dzieci, Perspektywa prawna. Warszawa: Wolters Kluwer.

Kodeks rodzinny i opiekuńczy z dnia 25 lutego 1964 roku, Dz.U. Nr 9, poz. 59.

Kodeks cywilny z dnia 23 kwietnia 1964 roku, Dz.U. Nr 16, poz. 93.

Kodeks postępowania cywilnego z dnia 17 listopada 1964 roku, Dz.U. Nr 43, poz. 296.

Kodeks karny z dnia 6 czerwca 1997 roku, Dz.U. Nr 88, poz. 553.

Łętowski J. (1995). Prawo administracyjne dla każdego. Warszawa: Ecostar.

Postanowienie SN z 11 lutego 1997 roku. II CKN 90/96.

Radwański Z. (1991). Dobro dziecka. W: Konwencja o prawach dziecka a prawo polskie. Łopatka A. (red.). Warszawa: Wydawnictwo Sejmowe, s. 50-65.

Sitarz O. (2004). Ochrona praw dziecka w polskim prawie karnym na tle postanowień Konwencji o prawach dziecka. Katowice: Wydawnictwo Uniwersytetu Śląskiego.

Sokołowski T. (2013). Kodeks rodzinny i opiekuńczy. Komentarz. Warszawa: Wydawnictwo: Wolters Kluwer, s. 667-668.

Soriano A. (2002). Przemoc wobec dzieci. Kraków: Wydawnictwo eSPe.

Trocha O. (2015). Udział dzieci w postępowaniu o ograniczenie władzy rodzicielskiej raport z badań aktowych. Dziecko krzywdzone. „Teoria, badania, praktyka”, vol. 14 , $\mathrm{nr}$ 4, s. 55-81.

Uchwała SN z 30 grudnia 1971 roku. III CZP 87/71, OSN 1972, Nr 6, poz. 104.

Uchwała SN z 6 czerwca 2000 roku. I CKN 786/98, OSNC 2001, Nr 1, poz. 6.

Ustawa prawo o aktach stanu cywilnego z dnia 28 listopada 2014 roku, Dz.U. z 2014 roku, poz. 1741.

Ustawa $\mathrm{z} 10$ czerwca 2010 roku o zmianie ustawy o przeciwdziałaniu przemocy w rodzinie oraz niektórych innych ustaw, Dz.U. Nr 125, poz. 842.

Ustawa z dnia 29 lipca 2005 roku o przeciwdziałaniu przemocy w rodzinie, Dz.U. Z 2015 roku, poz. 1390 oraz z 2019 roku, poz. 730.

Wilk A. (2019). Ograniczenie władzy rodzicielskiej jako forma jej wsparcia - rola wspótpracy sadu opiekuńczego i jednostki wsparcia rodziny. W: Prawa dziecka. Perspektywa prywatnoprawna i społeczna. Jaroszewska-Choraś D. (red.). Kilińska-Pękacz A., Wedeł-Domaradzka A., Gdańsk: Wydawnictwo Naukowe Katedra, s. 227-247.

Wyrok SN z 27 lutego 1967 roku. II CR 470/66, OSNCP 1967, Nr 9, poz. 167.

Wyrok SN z 2 grudnia 1971 roku. III URN 23/71, OSN 1972, Nr 3, poz. 50.

Wyrok SN z 5 września 1975 roku. I CR 526/75, OSN 1976, Nr 7-8, poz. 171. 
Wyrok SN z 7 czerwca 1976 roku. IV CR 177/76, OSPiKA 1977, Nr 5, poz. 85. Wyrok SN z 22 kwietnia 1977 roku. I CR 125/77, OSPiKA 1979, Nr 2, poz. 25. Wyrok SN z 13 grudnia 2000 roku. III CKN 1422/oo, OSNC 2001, Nr 7-8, poz. 106. Wyrok SN z 6 lutego 2009 roku. IV CSK 447/o8, MoP 2009, Nr 5, s. 244. Wyrok SN z 13 grudnia 2013 roku. SNO 35/13.

\section{OCHRONA DZIECKA Z PERSPEKTYWY CYWILNOPRAWNEJ - WYBRANE ZAGADNIENIA}

Streszczenie: Jednym z głównych celów ustawodawcy jest troska o dobro najmłodszych członków rodziny. Prawidłowo funkcjonująca rodzina nie wymaga ingerencji państwa do czasu, gdy przestanie ona odbiegać od powszechnie obowiązujących standardów. W takiej sytuacji niezbędne jest podjęcie mechanizmów prawnych, których celem będzie przywrócenie prawidłowego funkcjonowania rodziny. W związku z powyższym różne gałęzie prawa normują instrumenty mające pomóc rodzinie wyjść z kryzysu, w którym się znalazła. Artykuł przedstawia wybrane obszary cywilnoprawnej ochrony dziecka. Zaprezentowane zostały takie zagadnienia, jak: zakaz stosowania kar cielesnych względem małoletniego wraz ze skutkami jego złamania, inne formy nadużywania władzy rodzicielskiej, a także regulacje niektórych stosunków między rodzicami i dziećmi.

Słowa kluczowe: ochrona dziecka, prawo cywilne, kary cielesne, uprowadzenie dziecka, stosunki między rodzicami a dziećmi. 